\title{
Pelatihan Pembuatan Soal Ujian Online dengan Memanfaatkan Google Form untuk Guru-Guru SMP Negeri 42 Palembang
}

\author{
Wijang Widhiarso ${ }^{1}$, Ahmad Farisi ${ }^{2}$, Dafid ${ }^{2}$ \\ Universitas Multi Data Palembang, Jl. Rajawali No. 14 Palembang ${ }^{1,2,3}$ \\ Email: wijang@mdp.ac.id
}

\begin{abstract}
ABSTRAK
Pandemi Covid19 menjadi tantangan tersendiri di Indonesia dalam menyelenggarakan pendidikan daring. Sistem pembelajaran daring (dalam jaringan) merupakan sistem pembelajaran tanpa tatap muka secara langsung antara guru dan siswa tetapi dilakukan secara online yang menggunakan jaringan internet. Aktivitas-aktivitas yang dilakukan dalam pembelajaran daring diantaranya adalah kegiatan belajar mengajar dengan tatap muka online, pemanfaatan learning management system, hingga pelaksanaan ujian secara online. Pelaksanaan ujian online dapat dilakukan dengan menggunakan berbagai media online, seperti memanfaatkan fitur-fitur ujian yang terdapat dalam Learning Management System (LMS) moodle, edmodo, schoology, dan lain-lain. Salah satu alternatif yang dapat digunakan sebagai media pelaksanaan ujian online yang dinilai cukup mudah dan tidak berbayar adalah dengan memanfaatkan Google Form. Kegiatan pengabdian masyarakat ini dilakukan dalam bentuk pelatihan pembuatan soal ujian online menggunakan Google Form bagi guru-guru SMP Negeri 42 Palembang. Berdasarkan kuesioner yang disebarkan setelah pelatihan dilaksanakan, materi yang disampaikan dalam pelatihan sangat sesuai dengan kebutuhan para peserta pelatihan dan berdampak pada keinginan para peserta untuk menerapkan pelatihan tersebut dalam bentuk pembuatan soal ujian online menggunakan Google Form pada pelaksanaan Ujian Tengah Semester (UTS).
\end{abstract}

Kata kunci : Covid19, Guru, Pembelajaran Daring, Ujian Online, Google Form

\begin{abstract}
The Covid19 pandemic is a challenge for Indonesia in providing online education. The online learning system is a learning system without face-to-face learning between teachers and students but it is conducted using the internet. The activities of online learning are face-to-face online teaching and learning activities, the use of a learning management system, and the implementation of online exams. Online exam implementation can be conducted using various online media, such as the features in some Learning Management System (LMS) like Moodle, edmodo, schoology, and others. One alternative that can be used as a tools for conducting online exams which is considered quite easy and free of charge is Google Forms. This community service activity is carried out in the form of training in making online exam questions using Google Form for teachers of SMP Negeri 42 Palembang. Based on the questionnaire that was distributed after the training was conducted, the material presented in the training was very much in accordance with the needs of the training participants and had an impact on the participants' desire to apply the result of training in the form of making Include a maximum of five keywords or phrases online exam questions using Google Form in the implementation of the Mid-Semester Examination.
\end{abstract}

Keywords: Covid19, Teacher, Online Learning, Online Exams, Google Form 


\section{PENDAHULUAN}

Pandemi Covid19 menjadi tantangan tersendiri bagi di Indonesia dalam menyelenggarakan pendidikan daring. Di Indonesia sendiri perkembangan teknologi masih belum merata, menurut (Subiakto, 2013) umumnya hanya masyarakat di daerah perkotaan saja yang memiliki akses teknologi yang lebih baik sedangkan masyarakat di daerah perdesaan belum bisa mendapatkan akses komputer yang bagus, jaringan internet yang cepat dan layanan telepon yang baik. Selain itu menurut Pusdatin Kemendikbud (Suharwoto, 2020), adanya ketimpangan teknologi antar sekolah besar dan daerah serta keterbatasan sumber daya untuk pemanfaatan teknologi pendidikan seperti internet dan kuota menjadi tantangan bagi Indonesia selama pandemi Covid-19 ini.

Dalam menghadapi tantangan tersebut, pemerintah mendukung pembelajaran daring dengan mengeluarkan Peraturan Menteri Pendidikan dan Kebudayaan Republik Indonesia Nomor 68 Tahun 2014 Tentang Peran Guru Teknologi Informasi dan Komunikasi dan Guru Keterampilan Komputer dan Pengelolaan Informasi dalam Implementasi Kurikulum 2013 (Kemendikbud Republik Indonesia, 2014). Terlebih lagi dalam situasi pandemi Covid19 yang sedang melanda saat ini membuat pembelajaran daring menjadi solusi keberlangsungan pendidikan, khususnya di Indonesia, sehingga kegiatan pendidikan tetap dapat berlangsung, meskipun dilakukan dari rumah.

Sistem pembelajaran daring (dalam jaringan) merupakan sistem pembelajaran tanpa tatap muka secara langsung antara guru dan siswa tetapi dilakukan secara online yang menggunakan jaringan internet (Harnani, 2020). Aktivitas-aktivitas yang dilakukan dalam pembelajaran daring diantaranya adalah kegiatan belajar mengajar dengan tatap muka online, pemanfaatan learning management system, hingga pelaksanaan ujian secara online.

Beberapa pengabdian masyarakat telah dilaksanakan oleh akademisi-akademisi di Indonesia dalam rangka mendukung pelaksanaan pembelajaran daring di sekolah-sekolah, baik sekolah dasar, menengah pertama, maupun menengah atas. Seperti pelatihan penyusunan soal berbasis komputer menggunakan WQC yang dilakukan di Sekolah Menengah Negeri 1 Tinondo (Nasrum, 2020). Pelatihan ini memperlihatkan statistik bahwa sebanyak 16,67\% peserta pelatihan sangat paham dengan substansi pelatihan, sementara 83,33\% lainnya paham. Hasil nyata yang diperoleh setelah kegiatan pengabdian tersebut dilaksanakan adalah salah satu dari beberapa guru sekolah langsung menerapkan hasil pelatihan kepada siswa SMP untuk ujian tengah semester. 
Sejalan dengan itu, (Amin, Maulani, Pratama, \& Mahalisa, 2020) juga melakukan pengabdian masyarakat dalam bentuk pelatihan pengimplemintasian sistem aplikasi soal ujian online untuk Sekolah Menengah Pertama (SMP) atau sederajat. Tools yang digunakan dalam pelatihan tersebut adalah Open Source Computer Based Test. Kegiatan tersebut dilaksanakan di SMP Negeri 9 Banjarmasin dan diikuti oleh para guru yang menjadi peserta kegiatan. Tujuan dari kegiatan tersebut adalah mensosialisasikan kepada para guru SMP agar dapat menggunakan aplikasi ujian online sebagai alternatif untuk ujian.

Pelaksanaan ujian online dapat dilakukan dengan menggunakan berbagai media online, seperti memanfaatkan fitur-fitur ujian yang terdapat dalam Learning Management System (LMS) moodle, edmodo, schoology, dan lain-lain (Simarmata, 2020). Salah satu alternatif yang dapat digunakan sebagai media pelaksanaan ujian online yang dinilai cukup mudah dan tidak berbayar adalah dengan memanfaatkan Google Form.

Google Form merupakan salah satu bagian dari aplikasi Google Suite yang digunakan untuk kebutuhan pembuatan formulir online. Dalam perkembangannya, Google Form dapat digunakan juga untuk pelaksanaan ujian online, mulai dari pembuatan soal ujian beserta kunci jawaban, pelaksanaan ujian, hingga publikasi hasil ujian.

Dalam pembicaraan bersama kepala SMP Negeri 42 Palembang, Bpk. H. Yusuf Alaydrus, M. Pd., dalam mendukung pembelajaran online di era pandemi saat ini, guruguru di lingkungan SMP Negeri 42 Palembang membutuhkan keterampilan dan pemahaman teknologi informasi yang dapat menunjang pelaksanaan ujian online di SMP Negeri 42 Palembang. Oleh karena itu, pengabdian masyarakat ini dilaksanakan di SMP Negeri 42 Palembang dengan bentuk pelatihan yang ditujukan kepada guru-guru dengan tema pelatihan pembuatan soal ujian online. Berdasarkan uraian sebelumnya, media yang diusulkan dalam pelatihan ini adalah Google Form.

\section{METODE}

Kegiatan pengabdian kepada masyarakat ini dilakukan dalam bentuk pelatihan. Adapun metode yang digunakan dalam pelatihan ini adalah pendidikan masyarakat dan pelatihan yang mengacu pada (Morelli, 2015). Metode ini digunakan dalam bentuk pelatihan dan penyuluhan yang disertai dengan demonstrasi atau praktik bersama dalam pembuatan soal ujian online menggunakan Google Form.

Beberapa tahapan yang dilakukan dalam pelaksanaan kegiatan pengabdian kepada masyarakat ini adalah sebagai berikut : 
1. Survei Kebutuhan. Survei ini dilakukan untuk memetakan kompetensi apa yang dibutuhkan di lokasi pengabdian. Pada tahapan inilah diputuskan topik pelatihan adalah pembuatan soal ujian online.

2. Persiapan. Persiapan yang dilakukan adalah persiapan administratif yang dibutuhkan sebagai syarat pelaksanaan pelatihan, pembuatan materi pelatihan, dan mempersiapkan kuesioner yang akan disebarkan kepada peserta sebelum dan sesudah pelatihan dilaksanakan.

3. Pelaksanaan pelatihan. Sebelum pelatihan dilaksanakan, terlebih dahulu disebarkan kuesioner yang bertujuan untuk melihat kesiapan dan harapan peserta pelatihan. Secara umum kegiatan pelatihan berlangsung lancar.

4. Evaluasi. Kegiatan evaluasi dilakukan setelah pelatihan. Evaluasi dilakukan dengan menyebarkan kuesioner yang bertujuan mengevaluasi pelatihan, baik dari sisi materi pelatihan, hingga cara penyampaian instruktur, serta saran dan kritik dari para peserta kepada tim pengabdi.

\section{HASIL, PEMBAHASAN, DAN DAMPAK}

Sebelum pelatihan dilakukan, tim pengabdi menyebarkan kuesioner terlebih dahulu kepada 36 orang peserta pelatihan untuk memetakan kebutuhan, harapan, dan pemahaman para peserta terhadap pelatihan pembuatan soal ujian online dengan menggunakan Google Form. Hasil kuesioner tersebut menunjukkan data sebagai berikut.

- $16,6 \%$ peserta pernah membuat soal ujian online, sementara $83,4 \%$ peserta belum pernah membuat soal ujian online.

- $8,3 \%$ peserta pernah menggunakan Google Form, sementara 91,7 \% peserta belum pernah menggunakan Google Form

- $8,3 \%$ peserta juga pernah menggunakan Google Form untuk membuat soal ujian online, sementara 91,7\% peserta belum pernah menggunakan Google Form untuk membuat soal ujian online.

- $100 \%$ peserta menyatakan tertarik untuk mengikuti pelatihan pembuatan soal ujian online menggunakan Google Form.

Hasil kuesioner di atas memberikan gambaran tentang tingginya kebutuhan peserta terhadap pelatihan pembuatan soal ujian online dengan menggunakan Google Form, khususnya di masa pandemi yang menuntut para guru untuk siap dalam pelaksanaan pendidikan daring. 


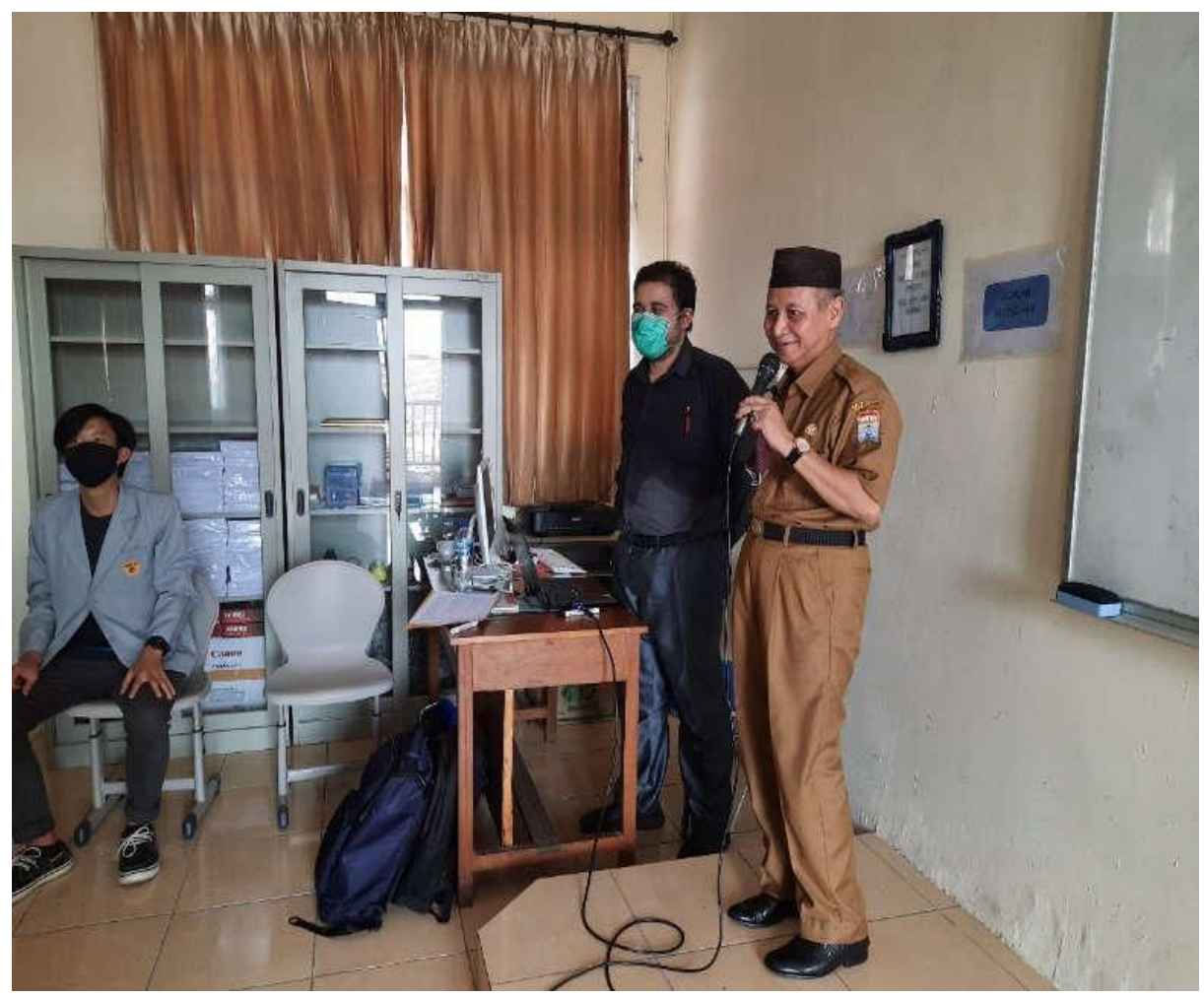

Gambar 1. Kepala SMP Negeri 42 Palembang memberikan arahan di tengah pelatihan

Setelah pelaksanaan pelatihan, tim pengabdi kembali membagikan kuesioner pasca pelatihan yang bertujuan untuk mengevaluasi pelatihan, baik dari sisi materi pelatihan, hingga cara penyampaian instruktur, serta saran dan kritik dari para peserta kepada tim pengabdi. Hasil dari kuesioner evaluasi tersebut adalah sebagai berikut.

- 91,7 \% peserta menyatakan bahwa pelatihan ini berlangsung dengan sangatbaik, sementara $8,3 \%$ menyatakan baik.

- $77,7 \%$ peserta menyatakan bahwa materi pelatihan ini sangat sesuai dengan kebutuhan peserta, sementara $22,3 \%$ menyatakan sesuai.

- $86,1 \%$ peserta menyatakan bahwa tim pengabdi telah menyampaikan pelatihan dengan sangat baik, sementara $13,9 \%$ peserta menyatakan baik.

- $100 \%$ peserta menyatakan bahwa peserta akan membuat soal ujian online menggunakan Google Form setelah pelatihan dilaksanakan. 


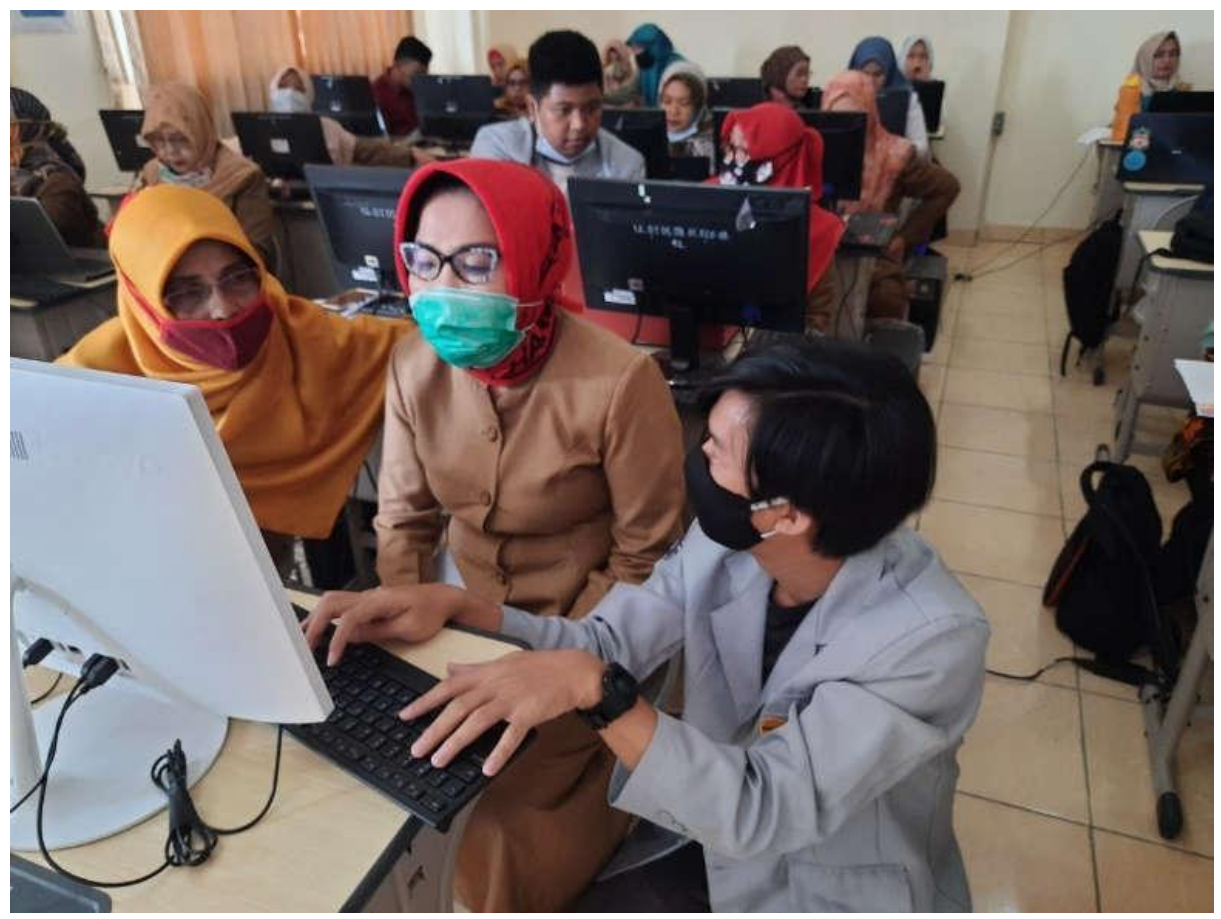

Gambar 2. Suasana saat pelaksanaan pelatihan

Hasil kuesioner tersebut memberikan gambaran bahwa materi pelatihan sangat sesuai dengan kebutuhan para peserta pelatihan dan berdampak pada keinginan para peserta untuk menerapkan pelatihan tersebut dalam bentuk pembuatan soal ujian online menggunakan Google Form pada pelaksanaan Ujian Tengah Semester (UTS).

\section{SIMPULAN}

Kesimpulan dari kegiatan pengabdian kepada masyarakat yang telah dilaksanakan dalam bentuk pelatihan pembuatan soal ujian online dengan memanfaatkan Google Form di SMP Negeri 42 Palembang adalah sebagian besar guru yang menjadi peserta pelatihan dapat mengikuti pelatihan dan dapat membuat formulir, soal ujian online beserta kunci jawabannya menggunakan Google Form. Pelatihan ini dapat diterapkan ke dalam bentuk ujian online, baik untuk ujian tengah semester, maupun ujian akhir semester.

Pelatihan ini diharapkan menjadi rangsangan positif bagi para guru untuk dapat meningkatkan kemampuan dan keterampilan yang dapat berpengaruh dalam kegiatankegiatan mengajar, khususnya kegiatan mengajar online yang dilakukan saat ini dalam kondisi pandemi Covid19. 


\section{DAFTAR PUSTAKA}

Amin, M., Maulani, J., Pratama, S., \& Mahalisa, G. (2020). Pelatihan Pengimplemintasian Sistem Aplikasi Soal Ujian Online Untuk Sekolah Menengah Pertama ( Smp ) Atau Sederajat. Hasil-Hasil Pengabdian Kepada Masyarakat Tahun 2020 Dosen-Dosen Universitas Islam Kalimantan, 242-249. Banjarmasin: Universitas Islam Kalimantan.

Harnani, S. (2020). EFEKTIVITAS PEMBELAJARAN DARING DI MASA PANDEMI COVID-19. Diambil 15 November 2020, dari BDK Jakarta website: https://bdkjakarta.kemenag.go.id/berita/efektivitas-pembelajaran-daring-di-masapandemi-covid-19

Kemendikbud Republik Indonesia. (2014). PERATURAN MENTERI PENDIDIKAN DAN KEBUDAYAAN REPUBLIK INDONESIA NOMOR 68 TAHUN 2014. Diambil $\quad 15 \quad$ November $2020, \quad$ dari http://simpuh.kemenag.go.id/regulasi/permendikbud_68_14.pdf

Morelli, N. (2015). Challenges in designing and scaling up community services. Design Journal, 18(2), 269-290. https://doi.org/10.2752/175630615X14212498964394 Nasrum, A. (2020). Pelatihan Penyusunan Soal Berbasis Komputer Menggunakan WQC. Jurnal Pengabdian Kepada Masyarakat MEMBANGUN NEGERI, 4(1), 7076. https://doi.org/10.35326/pkm.v4i1.587

Simarmata, J. (2020). Elemen-Elemen Multimedia untuk Pembelajaran (T. Limbong, Ed.). Medan: Yayasan Kita Menulis.

Subiakto, H. (2013). Internet untuk pedesaan dan pemanfaatannya bagi masyarakat. Jurnal Masyarakat, Kebudayaan dan Politik, 26(4), 243-256. Diambil dari http://journal.unair.ac.id/download-fullpapers-mkpa4d7ec1aaefull.pdf

Suharwoto, G. (2020). Pembelajaran Online di Tengah Pandemi Covid-19, Tantangan yang Mendewasakan. Diambil 20 Mei 2021, dari pusdatin.kemdikbud.go.id website: https://pusdatin.kemdikbud.go.id/pembelajaran-online-di-tengah-pandemi-covid-19tantangan-yang-mendewasakan/ 